\title{
Application analysis of financial indicators
}

\author{
TuYunYou, Xing Wei \\ Chengdu Aeronautic Vocational and Technical College, Chengdu, \\ 610100, China
}

\begin{abstract}
This article applied financial index analysis method, combining with the concrete enterprise financial indicators to evaluate the financial position and operating results of enterprise, through detailed analysis to the enterprise operation ability, debt paying ability, profit ability and development ability, it had a more profound understanding to enterprise's financial position and elastic, operating results and performance, service level and efficiency, commercial credit and risk, development trend and potential, and the overall situation of corporate finance.

Keywords: Financial analysis; Financial indicator; Analysis method
\end{abstract}

\section{Introduction}

Now enterprises all use a variety of different methods of financial statement analysis, to analyze the management present situation and development prospect of the enterprise, but no matter what kind of financial analysis methods companies use, ultimately focus on calculation and analysis of financial indicators, and using financial indicators to conduct financial statement analysis is the most basic and most important method. The so-called financial indicatorsare economic indicators that enterprises, by collecting the relevant financial data of production and business operation activities, analyze enterprise financing situationand calculate to reflect business and financial status of the enterprises, and it is get through the calculation to the data of enterprise financial report, which has a very important role and use in the development and management for enterprise, and more and more gets the attention of enterprises.

\section{Application analysis of financial indicators}

Table 1 is the comparison situation of a variety of financial indicators Bohai piston factory in 2008-2011.Through analysis of the following financial data rate, we can understand the financial and operating situation of the enterprises in recent years, and analyze enterprise debt paying ability, operation ability, profit ability and development ability,to put forward some constructive opinions and suggestions to the enterprise development present situation and the problems now in existence. 
Table 1 Financial figures of Bohai piston factory

\begin{tabular}{|c|c|c|c|c|}
\hline Accounting year & $2008-12-31$ & 2009-12-31 & $2010-12-31$ & 2011-12-31 \\
\hline \multicolumn{5}{|l|}{ Debt ratio } \\
\hline Liquidity ratio & 1.04 & 1.29 & 1.29 & 1.66 \\
\hline Quick ratio & 0.84 & 1.03 & 1.00 & 1.21 \\
\hline Cash ratio & 0.53 & 0.36 & 0.30 & 0.41 \\
\hline Equity Debt ratio & 0.40 & 0.54 & 0.63 & 0.79 \\
\hline $\begin{array}{l}\text { Inventory current } \\
\text { liabilities ratio }\end{array}$ & 0.20 & 0.25 & 0.29 & 0.45 \\
\hline \multicolumn{5}{|l|}{ Profitability } \\
\hline Return on equity & 0.05 & 0.07 & 0.15 & 0.11 \\
\hline Return on total assets & 0.01 & 0.03 & 0.06 & 0.05 \\
\hline Main business profit ratio & 0.02 & 0.05 & 0.10 & 0.06 \\
\hline Operating profit ratio & 0.02 & 0.05 & 0.10 & 0.06 \\
\hline Ratio of profits to cost & 0.02 & 0.06 & 0.09 & 0.07 \\
\hline $\begin{array}{c}\text { Expense ratio during the } \\
\text { selling period }\end{array}$ & 0.14 & 0.16 & 0.12 & 0.11 \\
\hline Earnings retention ratio & 4.79 & 3.72 & 2.48 & 3.87 \\
\hline \multicolumn{5}{|l|}{ Operation ability } \\
\hline $\begin{array}{c}\text { Accounts receivable } \\
\text { turnover }\end{array}$ & 6.20 & 4.35 & 4.96 & 4.94 \\
\hline $\begin{array}{l}\text { Accounts receivable } \\
\text { payback period(days) }\end{array}$ & 58.09 & 82.83 & 72.59 & 72.86 \\
\hline Inventory turnover ratio & 3.85 & 3.54 & 4.86 & 4.43 \\
\hline $\begin{array}{l}\text { Inventory sales period } \\
\text { (days) }\end{array}$ & 93.55 & 101.62 & 74.11 & 81.25 \\
\hline Main profit share & 0.87 & 0.92 & 1.13 & 0.98 \\
\hline \multicolumn{5}{|l|}{ Financial capacity } \\
\hline Asset-liability ratio & 0.71 & 0.65 & 0.61 & 0.56 \\
\hline
\end{tabular}




\begin{tabular}{|c|c|c|c|c|}
\hline $\begin{array}{c}\text { Coefficient of rights and } \\
\text { interests }\end{array}$ & 3.48 & 2.87 & 2.59 & 2.27 \\
\hline Equity ratio & 2.47 & 1.87 & 1.58 & 1.26 \\
\hline \multicolumn{5}{|l|}{ Growth ability } \\
\hline Main business growth ratio & 0.04 & -0.15 & 0.44 & 0.03 \\
\hline $\begin{array}{l}\text { Growth rate of accounts } \\
\text { receivable }\end{array}$ & 0.03 & 0.56 & 0.10 & -0.10 \\
\hline Net profit growth ratio & -0.13 & 0.77 & 1.38 & -0.18 \\
\hline Total assets expansion ratio & 0.20 & -0.11 & 0.05 & -0.03 \\
\hline $\begin{array}{c}\text { Earnings per share growth } \\
\text { ratio }\end{array}$ & -0.42 & 0.77 & 1.38 & -0.18 \\
\hline Net asset growth ratio (\%) & 0.03 & 0.08 & 0.16 & 0.11 \\
\hline \multicolumn{5}{|l|}{ Cash flow } \\
\hline $\begin{array}{l}\text { Operating cash flows per } \\
\text { share (yuan) }\end{array}$ & 1.02 & 0.35 & 1.76 & 1.46 \\
\hline $\begin{array}{l}\text { Return on operating cash } \\
\text { flow of assets }(\%)\end{array}$ & 0.07 & 0.03 & 0.14 & 0.12 \\
\hline Main business cash ratio & 0.11 & 0.05 & 0.16 & 0.13 \\
\hline \multicolumn{5}{|l|}{ Single stock index } \\
\hline Net assets per share & 3.92 & 4.23 & 4.92 & 5.45 \\
\hline Earnings per share & 0.18 & 0.32 & 0.75 & 0.62 \\
\hline Main income per share & 8.89 & 7.51 & 10.86 & 11.20 \\
\hline Capital reserves per share & 2.06 & 2.06 & 2.06 & 2.06 \\
\hline
\end{tabular}

\subsection{Index analysis of debt paying ability of enterprise}

(1) The company's current ratio, from 1.04 in 2008 to 1.66 in 2011, liquidity ratio increases continuously, and it can be seen thatthe assets flow of enterprise increase, liquidity enhances, enterprise's short-term debt paying ability increases continuously, short-term solvency risk is smaller. The ability loss buffering capacity and to deal with uncertainty and emergency of enterprises enhance, and the safeguard level of principal and interest for corporate creditors rights and interests is also enhanced.But if liquidity indicator is excessive, it also suggests that firms may existproblems of poor idle waste, bad configuration, and the 
service efficiency of funds is not high, the use of the result is bad.Combined with industry standards, it shows that the current ratio of enterprises now is reasonable, which should be improved again based on it.

(2) The company's quick ratio wasrespectively 0.84, 1.03, 1, 1.21 from 2008 to 2011, and it can be seen the quick ratio of enterprise is improved to some extent.Although it has declined in 2010 than in 2009, the overall is on the rise. Because quick ratio has eliminated inventory with poor cashability in the short term, this index can reflect the short-term solvency of enterprises, and the improvement of the quick ratio shows the improvement of enterprise's short-term debt paying ability. Of course, we combined balance sheet to see that the increase $\mathrm{f}$ quick ratio is due to reduction of current liabilities and the increase of accounts receivable.If seeing only from the data, we may think enterprise's financial position is good, and quick ratio is rising, but along with the increase of accounts receivable, capital payback period of the enterprise has extended, the probability of bad debts occurrence also rises, therefore, we should strengthen enterprise accounts receivable management and recycling.So we should improve the quick ratio of enterprises from the mass, and not only from the data.

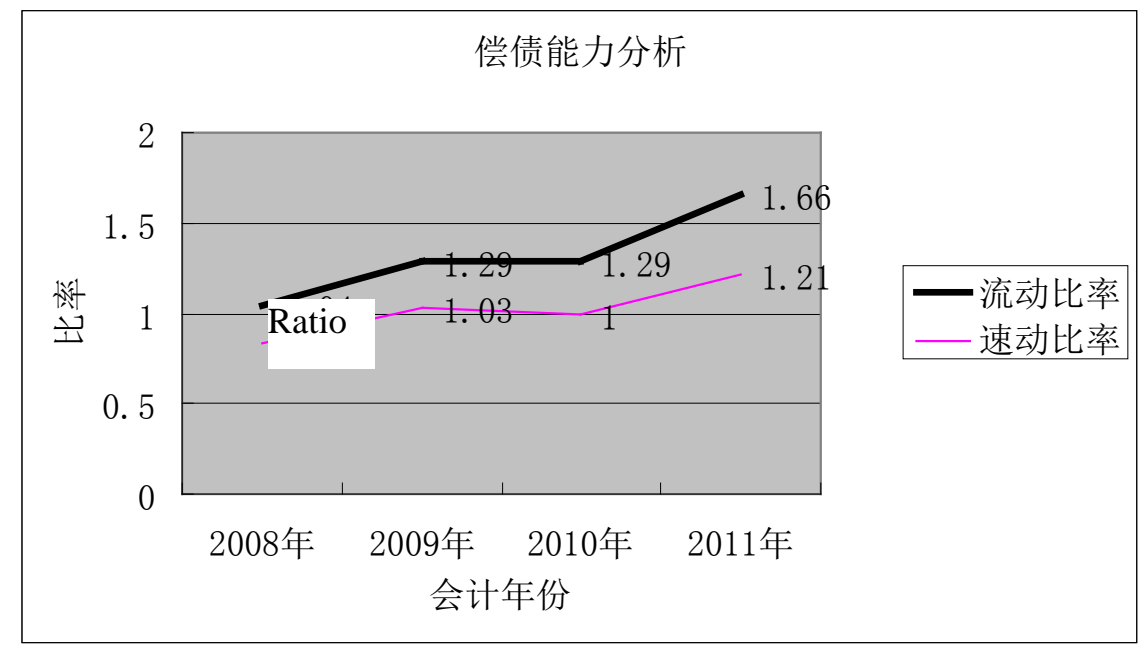

Figure 1

\subsection{Index analysis of profitability of enterprise}

(1) The first is to observe net assets yield ratio of enterprise, from 0.05 in 2008 to 0.15 in 2010, but it dropped to 0.11 in 2011, it can be seen thatthe profitability of the enterprise should be paid attentions. The index net assets yield ratio has the very strong comprehensiveness to reflect the financial position of the enterprise, which can be decomposed into the product of several indicators in DuPont analysis system.Combined with the income statement and balance sheet, we can find that in 2011 net assets yield ratio fell, because the decline of enterprise's sales profit rate and equity multiplier, enterprises should strengthen managements in both areas. 
(2) The second is to observe the total return on assets of the enterprise, from 0.01 in 2008 to 0.05 in 2011, and it shows that the net interest rate of the assets isstill rising steadily, declining in 2011 compared with 2010, but the overall has been improved.As we know that enterprise asset utilization efficiency is higher, the higher the index is, the higher the enterprise resource utilization is, the higher the value of earnings is, and vice versa. This index has a crucial relationship with how much enterprise capitalis, the structure ratio of the assets and operator's operation and management level.In 2011 net profit increased to some extent, but it is still relatively small relative to the increase of total assets, so the total assets yields went down,and we can know the enterprise asset utilization efficiency needs to be improved.

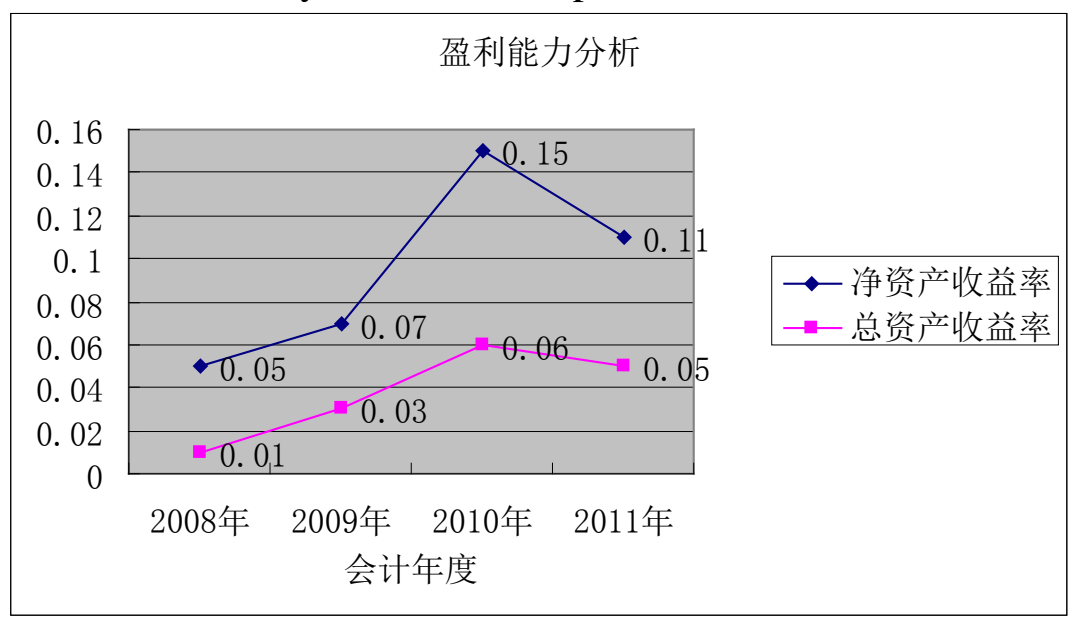

Figure 2

\subsection{Index analysis of operation capacity profitability of enterprise}

(1) The accounts receivable turnover ratio (number) is 6.2 times in 2008, reduced to 4.94 times in 2011, and it can be seen that the turnover times of enterprises were continuously falling, leading to the increasing turnover days, so the enterprise account receivable management is faced with some problems.Combining with enterprise financial reports, w can find that accounts receivable turnover went down, due to the increase of the ending balance of accounts receivable, under the situation that sales is relatively constant, the increase of the ending balance of accounts receivable makes turnover timesgo down, which shows that the enterprise accounts receivable collection speed and the efficiency of management work need to be strengthened, also indicates the type of enterprise credit policy, liquidity of assets and quality of profitability face with problems, so the company should start from its accounts receivable management, review whether its credit policy and terms of payment are reasonable, formulate more effective credit policy, improve the recovery speed and efficiency of enterprise funds, reduce the risk of bad debts in enterprises, 
improve the utilization efficiency of enterprise liquid assets, and enhance enterprise's short-term solvency and liquidity of enterprise assets.

(2) The inventory turnover (number) from 3.85 times in 2008 to 4.43 in 2011, although it in 2011 declined to some extent compared with 2010, but the overall appears the rise trend, leading to the decrease of inventory turnover days, which shows that the enterprise inventory management efficiency is improved, stock capital turnover speeds up, the overall operating efficiency and inventory management efficiency has been improved, and all sorts of operating capacity and profitability of enterprise are improved.But at the same time, the index is not enough to comprehensively evaluate enterprise operating performance and the inventory management level, and the trend in 2011 declined, so the enterprise should combine with the enterprise and its industry average inventory turnover to analyze, and it can be seen that enterprise inventory turnover rate is relatively low at present, which still needs to continue to strengthen.

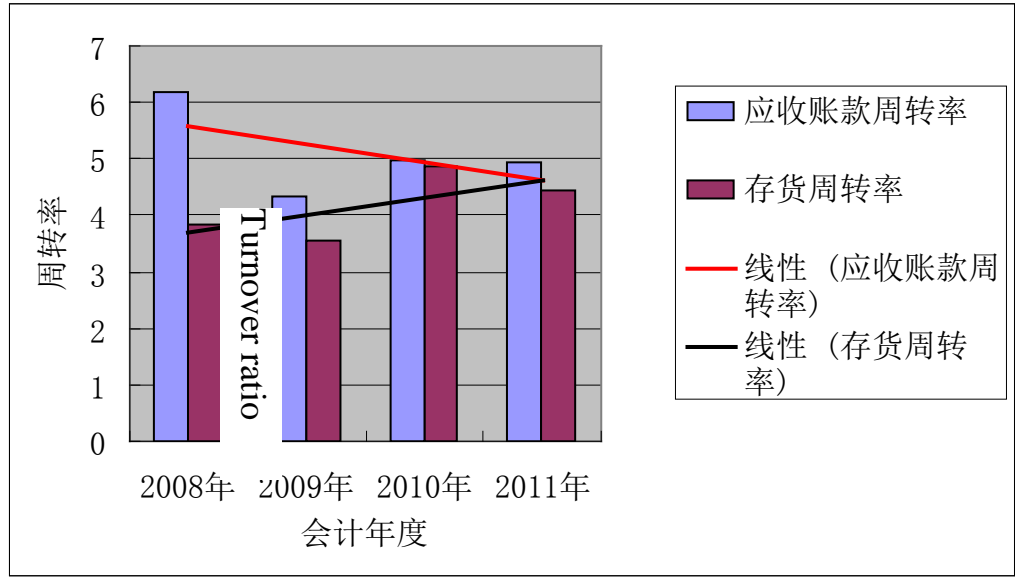

Figure 3

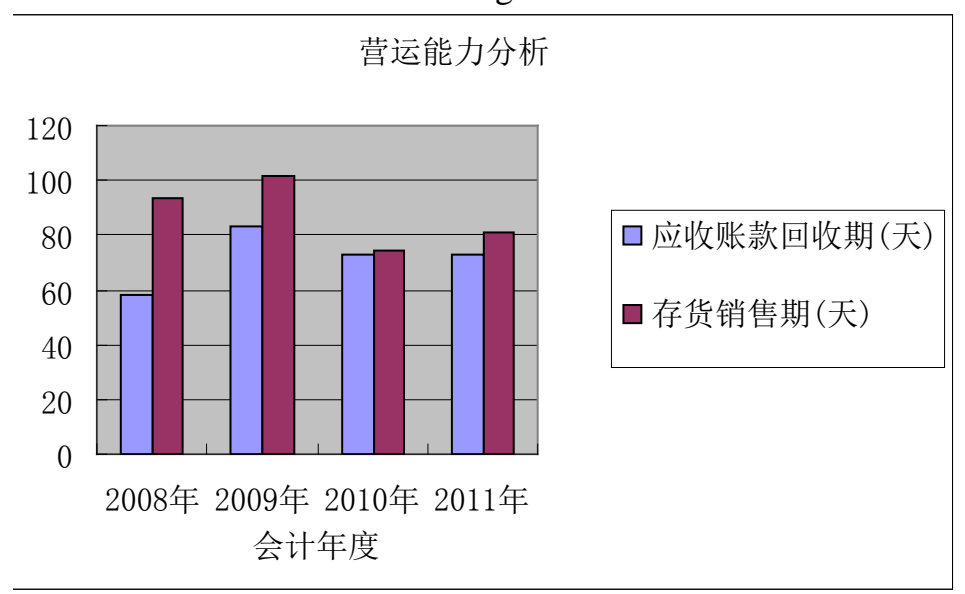

Figure 4 


\subsection{Index analysis of financial capacity profitability of enterprise}

(1) The assets-liabilities rate of enterprises in 2008 and 2008, are respectively $2.47,1.87,1.58,1.87$, so asset-liability ratio is declining, which shows that owned assets in the enterprise assets increase, the liabilities rate is falling and the long-term financial risk to the enterprise is falling, debt risk also fell to some extent, and the enterprise long-term debt paying ability enhance, which is conducive to the interests protection of the creditors, at the same time, enhancing the confidence of enterprise to lend its own funds.But at the same time, falling asset-liability ratio also shows that utilization degree of the enterprise for the creditors funds is not high, the role of enterprise financial leverage was not fully played, and the enterprise needs to carefully look at the discretion of the asset-liability ratio, and combines with their specific conditions to formulate rational and effective rate.In terms of industry standards of enterprise industry, the enterprise's asset-liability ratio is too high at present, and the profitability of enterprises is limited to a certain degree.

(2) The equity ratio from 2.47 in 2008 to 1.26 in 2011, further reflected that the enterprise's debt capital fell sharply, and the declineof equity ratio shows the debt risk of the enterprise is falling, and the financial structure of enterprise tends to be low risk development, then the decrease of corporate debt ratio make the immediate interests of the creditors be more likely to get guarantee and implementation.But the ability of enterprise to use debt capital to profit declined to some extent, the role of financial leverage also dropped.The capital structure is unreasonable, so the enterprise should combine with its strategic intent, financial goals and risk level, adopt flexible and effective adjustment measures, optimize capital structure and enhance profitability.

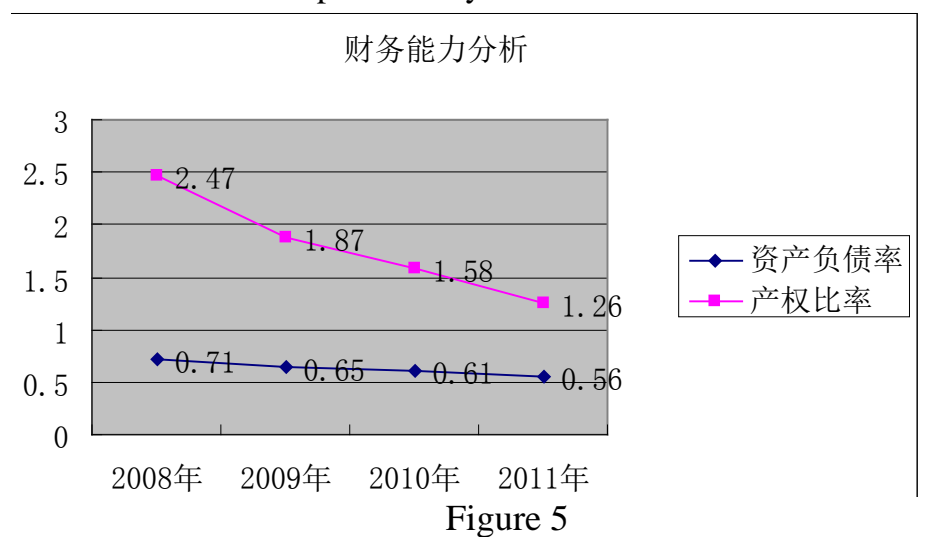

\section{Improvement measures of enterprise financial management}

Combined with the enterprise's current financial indicators, corporate asset-liability ratio declines continuously, and current assets is also on the rise, therefore, we should be aware in terms of liquidity, refer to the industry standard, analyzewhether enterprise liquidity is too much combined with the specific 
situation of the enterprise itself, and pay attention to increase strength and scope of long-term investmentto improve the profit level of the enterprise itself, promoting the long-term development of the enterprise. In the case of enterprise with major liquid assets, corporate asset-liability ratio declines continuously, making the ability of enterprise to use external capital to profit decline to some extent, so enterprise should be the premise of in connection with their development strategic objectives, properly adjudge the asset-liability ratio of enterprises, and make full use of the advantages of low capital cost of debt capital to reduce the cost.

\section{References}

1. [1]Li Yong. Profit quality analysis of China Southern Airlines[D]. University of International Business and Economics, 2011.

2. [2]An Hui,XieYangchun. Financial analysis[M]. China Railway Publishing House, 2009.

3. [3] Zhang Yabin, etc.Listed company's profitability from the financial report[J].Journal of Business Accounting, 2010.

4. [4] BinZhouBohai piston co., LTD. Web site.Financial and accounting reports and financial data from 2008 to 2011.HexunWeb. 